\title{
Effect of Stress on Ontogeny of Humoral Immunity in Catla
}

\author{
Purandara Ballyaya Abhiman ${ }^{1}$, Md. Abdullah-Al Mamun ${ }^{1,2, *}$, Manjulesh Pai ${ }^{1}$, \\ Shamima Nasren ${ }^{1,3}$, Sanjay Singh Rathore ${ }^{1}$ and Kalkuli Mariappa Shankar ${ }^{1}$
}

\author{
${ }^{1}$ Laboratory of Aquatic Health Management, Department of Aquaculture, College of Fisheries, Mangalore-575002, Karnataka Veterinary \\ Animal and Fisheries Science University, Karnataka, India. ${ }^{2}$ Department of Fish Health Management, Sylhet Agricultural University, Sylhet- \\ 3100, Bangladesh. ${ }^{3}$ Department of Fish Biology and Genetics, Sylhet Agricultural University, Sylhet-3100, Bangladesh .
}

Received: May 9, 2020; Revised: Dec 22, 2020; Accepted: January 12, 2021

\begin{abstract}
The present study aimed to evaluate the crowding and handling stress with increased cortisol production, its effect on growth and ontogeny of humoral immunity in Catla catla. Fishes were stressed at different stocking densities $\left(T_{1}, T_{2}, T_{3}\right.$ and $\left.T_{4}\right)$ in crowding stress and were monitored for various parameters including length, weight, serum cortisol and immunoglobulin. In comparison to low stocking density group $T_{1}\left(3000 / \mathrm{m}^{2}\right)$, high stocking groups $\left(\mathrm{T}_{2}, \mathrm{~T}_{3}\right.$ and $\left.\mathrm{T}_{4}\right)$ showed reduction in both average length and weight on 6th day onwards up to 40th day. The results of $T_{4}\left(18000 / \mathrm{m}^{2}\right)$ showed drastic reduction up to 12th day and died afterwards. Similarly, in handling stress fishes were stocked in six hapas at equal densities $\left(3000 / \mathrm{m}^{2}\right)$ with different stress $\left(\mathrm{HS}_{1}, \mathrm{HS}_{2}, \mathrm{HS}_{3}, \mathrm{HS}_{4}, \mathrm{HS}_{5}\right.$ and $\mathrm{HS}_{6}$ ) revealed a decrease in average length and weight in comparison to control throughout the study period. Serum cortisol levels were significantly elevated $(\mathrm{P}<0.05)$ in higher crowding and handing stress groups. The results of ELISA for crowding stress showed that immunoglobulins were detectable in the spawn from 3 days post hatching (DPH). The immunoglobulin levels decreased till $18 \mathrm{DPH}$ in $\mathrm{T}_{2}, \mathrm{~T}_{3}$ and $\mathrm{T}_{4}$ groups, although the levels were significantly higher $(\mathrm{P}<0.05)$ in lower stocking density group $\left(\mathrm{T}_{1}\right)$. In response to handling, all the stressed groups showed significant decrease $(\mathrm{P}<0.05)$ in immunoglobulin production in comparison to control at $18 \mathrm{DPH}$ onwards. A slow recovery was observed on 40th day, although the immunoglobulin levels in stressed groups were remained lesser than the control.
\end{abstract}

Keywords: Stress, Cortisol, Humoral, Immunoglobulin, ELISA, Catla catla

\section{Introduction}

The maintenance of good fish health is critical to profitable fish culture. Aqua cultural ecosystems are innately unstable, unnatural environments. In general, the greater the culture intensity, the greater is the environmental instability. Fishes are exposed to various stressors under natural and cultural conditions (Sharma et al., 2016; Tengjaroenkul and Neeratanaphan, 2020). Alteration of water salinity, $\mathrm{pH}$, hardness, alkalinity, dissolved solids, water level or current, inadequate nutrition and exposure to waterborne pathogens or toxicants are the common stressors for fish (Harper and Wolf, 2009, Lavanya et al., 2011). The procedural stressors include handling, crowding, netting, sorting, vaccine administration etc. Stressors may be acute or chronic and their impacts on fish are additive and cumulative at least for a short period. The extent of stress may vary with nature of stress and its duration and dependable upon age, sex, maturation stage, species and strain of the fish (Perumal et al., 2015). Fish react to stress with a primary neuroendocrine response, represented by a rapid hyper secretion of catecholamines (adrenaline and noradrenaline) and corticosteroids (mainly cortisol) into the blood stream (Pickering, 1981). As a result of their high levels in the circulatory system, a wide range of secondary responses can be observed. The effects of these hormones at blood and tissue level include disturbance of the metabolic and hydro mineral balance. Tertiary responses include behavioral modifications, implications for fish growth and reproduction and increased susceptibility to diseases (Pickering et al., 1982; Pankhurst et al., 1997; Okpashi et al., 2018).

A variety of biochemical measurements are used as indicators of stress in fish. Among the most frequently measured variables, there are levels of circulating corticosteroid hormones (mainly cortisol) and glucose, lactate, haemoglobin, proteins and haematocrit (Poli et al., 2005). In addition, some components of innate immune system (e.g. lysozyme, haemolytic and haemagglutinating activity) and humoral factors such as IgM levels are used as indicators of immunocompetence in fish exposed to stress (Sunyer et al., 1995; Tort et al., 2004). The immune parameters including IgM are essential to measure the health status of fish and as markers for stress (Sahoo et al., 2005). The immune system in newly hatched larvae is not fully developed and they are exposed to a potentially pathogenically hostile environment (Breuil et al., 1997). The immunoglobulins detected in the eggs, hatchlings and the spawns are of maternal origin. The maternal transfer of IgM has been documented in several teleost fish including, tilapia (Oreochromis aureus) (Avtalion and Mor, 1992; Takemura, 1993), channel catfish, (Ictalurus punctatus)

\footnotetext{
* Corresponding author e-mail: mamunff@gmail.com.
} 
(Hayman and Lobb, 1993), chum salmon, (Oncorhynchus keta) (Fuda et al., 1992) and coho salmon Oncorhynchus kisutch (Yousif et al., 1995), Indian major carps (Bag et al., 2009). Limited research has been carried out relating with growth and humoral immune parameters with husbandry stress on early developmental stages in Indian Major Carps, Catla catla, an aquaculture potential species. The present study was undertaken in an attempt to explain the mechanism of growth inhibition, cortisol indication and humoral immunity by crowding and handling stress.

\section{Materials and methods}

\subsection{Seed collection and transportation}

Two day post hatch spawn of the Indian major carp, catla (Catla catla) used in the present study was procured from the fish seed farm, State Department of Fisheries, Bhadra Reservoir Project (BRP), Shimoga, Karnataka, India in packed plastic bags containing $1 / 3^{\text {rd }}$ water and $2 / 3^{\text {rd }}$ oxygen.

\subsection{Larval rearing}

The larvae were reared in hapas suspended in the freshly manured water (cow dung $10,000 \mathrm{~kg} / \mathrm{ha}$ ) of pretreated cement cisterns of size $25 \mathrm{~m}^{2}$ at the fish farm of College of Fisheries, Mangalore. The aquatic insects were eradicated by using Butox $\left(0.04 \mathrm{ml} / \mathrm{m}^{2}\right)$, one week after the manuring. Hatchlings were stocked at the rate of $1000 / \mathrm{m}^{2}$. Larvae were fed on the naturally available planktons; in addition, they were fed daily with rice bran and groundnut oil cake at a ratio $1: 1$ at $10 \%$ of the body weight. The experimental protocol lasted for 40 days and temperature variation was in the range of $21{ }^{\circ} \mathrm{C}$ to $26{ }^{\circ} \mathrm{C}$ during the entire study period.

\subsection{Stressing protocol}

\subsubsection{Crowding Stress}

The hatchlings were individually stocked in the hapas at the densities of 3000,6000, 12000 and 18000 per $\mathrm{m}^{2}$ in triplicate. The samples for cortisol and IgM estimation were collected from the experimental hapas using a hand net, on $3^{\text {rd }}, 6^{\text {th }}, 12^{\text {th }}, 18^{\text {th }}, 24^{\text {th }}, 30^{\text {th }}$ and $40^{\text {th }}$ day post hatching.

\subsubsection{Handling Stress}

Spawn were held in seven different hapas at equal stocking densities $\left(3000 / \mathrm{m}^{2}\right)$. Fishes of the one hapa were maintained as control without any handling. Fishes of the other six hapa were stressed according to the method of Feist and Schreck (2001) with slight modifications by holding them out of water for $30 \mathrm{sec}$ and releasing back to recover for a period for $15 \mathrm{~min}$, were stressed again two times by holding them out of water for 15 sec after 15 and 30 min of the original stressing. Fishes were sampled after 15 min of the last stressor. Fishes were sampled on $3^{\text {rd }}, 6^{\text {th }}$, $12^{\text {th }}, 18^{\text {th }}, 24^{\text {th }}$ and $30^{\text {th }}$ day post hatched. The lengthweight parameters were measured for the handled group $\mathrm{HS}_{1}$ (the group handled on 3rd day or 3DPH) and control group on the 3rd day. The group $\mathrm{HS}_{2}$ was handled only on 6 th day (when the larvae were 6DPH). The group $\mathrm{HS}_{3}$ was handled on 12th day, both the previously stressed groups $\mathrm{HS}_{1}$ and $\mathrm{HS}_{2}$ were sampled. The group $\mathrm{HS}_{4}$ was handled on the 18th day, the previously stressed groups $\mathrm{HS}_{1}, \mathrm{HS}_{2}$ and $\mathrm{HS}_{3}$ were sampled. Similarly $\mathrm{HS}_{5}$ and $\mathrm{HS}_{6}$ were handled on 24th day and 30th day respectively. On 40th day no handling was done, only sampling was done for all previously stressed groups

In case of both the stressing protocols, a pool of 100300 spawn and a pool of 5-30 fry fishes were used to prepare the cortisol and antibody extract solution. The number of individuals sampled decreased with increase in the fish body weight. Fish samples were collected from the experimental hapas using a hand net, immediately anesthetized, rinsed with distilled water and then with PBS (Phosphate Buffer Saline) (pH 7.4). Wet body weight and total length of the fish were recorded.

\subsection{Preparation of fish extracts for antibody extraction}

Spawn and fry extracts of both control and stressed groups were prepared according to the method of Breuil et al. (1997) with slight modification in rpm employed in centrifugation. The spawn and fry of catla were homogenized with three volumes of PBS $\mathrm{pH} 7.4$; and the resultant homogenate was centrifuged at $12000 \mathrm{rpm}$ for 15 min under $4^{\circ} \mathrm{C}$. The supernatants were collected, centrifuged twice at $12000 \mathrm{rpm}$ for $10 \mathrm{~min}$, and pooled supernatants were stored at $-40{ }^{\circ} \mathrm{C}$ with addition of Protease inhibitor cocktail (Sigma,USA) till use.

\subsection{Determination of protein concentration}

Protein concentration of tissue extracts of different samples of catla was determined according to Lowry et al. (1951) using protein estimation kit (Bangalore, Genei India Pvt. Ltd.)

\subsection{Monoclonal Antibody production from the hybridoma clone $C_{6} E_{2}$}

Hybridoma clones $\mathrm{C}_{6} \mathrm{E}_{2}$ raised against IgM of catla (Honnananda, 2008) were revived from the frozen state at $-196{ }^{\circ} \mathrm{C}$ by thawing at $37{ }^{\circ} \mathrm{C}$ in the water bath. The cell suspension was suspended in $10 \mathrm{ml}$ of serum (FBS) free RPMI cell culture medium. The cells were harvested by centrifuging at $1800 \mathrm{rpm}$. The supernatant was decanted and the cell pellet was re-suspended in $5 \mathrm{ml}$ RPMI medium enriched with 15\% FBS and distributed to 96 well tissue culture plate or $25 \mathrm{~cm}^{2}$ flask according to the cell density. The plates/flasks were incubated at $37^{\circ} \mathrm{C}$ in $\mathrm{CO}_{2}$ incubator and subsequently transferred to $75 \mathrm{~cm}^{2}$ flasks for production of monoclonal antibody (MAb).

\subsubsection{Enzyme- linked Immunosorbent Assay (ELISA)}

ELISA was carried out according to Furuta et al. (1995) with slight modifications. Microtitre plates were coated with tissue extract $(100 \mu \mathrm{l} /$ well $)$ diluted in carbonate-bicarbonate buffer ( $\mathrm{pH} 9.6$ ) to a concentration of $10 \mu \mathrm{g} / \mathrm{ml}$ protein and incubated overnight at $4{ }^{\circ} \mathrm{C}$. Unbound proteins were removed by washing once with PBS-T20 (0.05\% Tween-20 in PBS) subsequently with PBS with a 3 min interval. $300 \mu$ of PBS-5\% skimmed milk was added as a blocking reagent to each well and $2 \mathrm{~h}$ at room temperature. The blocking was followed by washing with PBS-T20 and PBS. 100 $\mu$ MAb was added to each well except to the antibody blank and incubated for $3 \mathrm{~h}$ at room temperature. The excess MAb was poured off and the plate was washed twice with PBS-T20 and once with PBS alone. The plates were then incubated for $45 \mathrm{~min}$ at room temperature by adding Rabbit anti mouse IgG peroxidase conjugate at 1:2000 dilution in 3\% BSA-PBS (Bangalore, Genie Pvt. Ltd.), washed three times PBS-T20 and once 
with PBS. The peroxidase activity was then measured by adding $100 \mu$ l of a substrate solution containing tetramethylebenzidine and hydrogen peroxide (TMB/ $\mathrm{H}_{2} \mathrm{O}_{2}$ ) diluted in distilled water at a ratio 1:20. After incubation for $10 \mathrm{~min}$ in the dark at room temperature, the enzyme reaction was stopped by adding $50 \mu \mathrm{l}$ of $2 \mathrm{~N}$ $\mathrm{H}_{2} \mathrm{SO}_{4}$ to each well and the optical density was measured at $450 \mathrm{~nm}$ using a Microplate reader (Bio-Tek Instruments, Inc. USA).

\subsection{Estimation of whole body cortisol levels}

\subsubsection{Preparation fish extracts for cortisol estimation}

Spawn and fry extracts of both control and stressed groups were prepared as previously described, except that the centrifugation was carried out at $3000 \mathrm{rpm}$ for $10 \mathrm{~min}$ at $4^{\circ}$ C. The supernatant was immediately analysed after processing.

\subsubsection{Determination of Cortisol levels in stressed fish by competitive ELISA}

Cortisol levels in the stressed (both crowding and handling) as well as control groups were measured using Cortisol Saliva Kit (Diagnostics Biochem Canada Inc.).Working solutions of the cortisol-HRP conjugate and wash buffer were prepared according to manufacturers' instructions. Each calibrator, control and stressed samples $50 \mu \mathrm{l}$ were pipetted into strips of labelled microwells in duplicates. The conjugate working solution of $100 \mu \mathrm{l}$ was dispensed into each well. The plate was then incubated on a plate shaker at $200 \mathrm{rpm}$ for $45 \mathrm{~min}$ at room temperature. The wells were washed three times with $300 \mu$ of diluted wash buffer per well and plate was tapped firmly against absorbent paper to ensure that it was dry. TMB substrate of $150 \mu \mathrm{l}$ was pipetted into each well at timed intervals and incubated on a plate shaker for $15-20 \mathrm{~min}$ at room temperature. $50 \mu \mathrm{l}$ of stopping solution was pipetted into each well and the plate was read on a Microplate reader (Bio-Tek Instruments, Inc. USA) at $450 \mathrm{~nm}$ within $20 \mathrm{~min}$ of addition of the stopping solution.

\subsection{Statistical analysis}

All data were expressed as mean \pm SE (standard error). Differences in the cortisol and immunoglobulin levels between the treatments were analysed statistically through one-way analysis of variance (ANOVA) followed by Duncan's multiple range test by using SPSS software (20.0 version). The level of significance was chosen at $\mathrm{P}<0.05$.

\section{Results}

\subsection{Measurement of average length and weight}

\subsubsection{Crowding stress}

The initial average length and weight of a sample of 3DPH larvae was measured before stocking. The mean length and weight were found to be $0.5 \mathrm{~cm}$ and $0.0015 \mathrm{~g}$ respectively (Table 1). Sampling was done for cortisol and IgM estimation was done on scheduled days up to $40^{\text {th }}$ day. In comparison to low stocking density group $T_{1}$ (3000/ $\mathrm{m}^{2}$ ), high stocking groups showed reduction in both average length and weight $6^{\text {th }}$ day onwards up to $40^{\text {th }}$ day. There has been slight variation observed among the groups $\mathrm{T}_{1}\left(3000 / \mathrm{m}^{2}\right)$ and $\mathrm{T}_{2}\left(6000 / \mathrm{m}^{2}\right)$. The results of $\mathrm{T}_{4}$ $\left(18000 / \mathrm{m}^{2}\right)$ showed drastic variation up to $12^{\text {th }}$ day in comparison to all other groups. In comparison to groups $T_{1}$ and $T_{2}$ the reduction in the average length and weight in the group $T_{3}\left(12000 / \mathrm{m}^{2}\right)$ was observed throughout the study period up to the $40^{\text {th }}$ day.

Table1. Average length and weight of catla subjected to crowding stress (CS)

\begin{tabular}{|c|c|c|c|c|c|c|c|c|}
\hline \multirow{2}{*}{$\begin{array}{l}\text { Sampling } \\
\text { days }\end{array}$} & \multicolumn{2}{|c|}{$\mathrm{T}_{1}\left(3000 / \mathrm{m}^{2}\right)$} & \multicolumn{2}{|c|}{$\mathrm{T}_{2}\left(6000 / \mathrm{m}^{2}\right)$} & \multicolumn{2}{|c|}{$\mathrm{T}_{3}\left(12000 / \mathrm{m}^{2}\right)$} & \multicolumn{2}{|c|}{$\mathrm{T}_{4}\left(18000 / \mathrm{m}^{2}\right)$} \\
\hline & $\mathrm{L}(\mathrm{cm})$ & W(g) & $\mathrm{L}(\mathrm{cm})$ & W(g) & $\mathrm{L}(\mathrm{cm})$ & W(g) & $\mathrm{L}(\mathrm{cm})$ & W(g) \\
\hline $3^{\text {rd }}$ day & $0.5 \pm 0.03$ & $0.0015 \pm 0.0002$ & $0.5 \pm 0.03$ & $0.0015 \pm 0.0002$ & $0.5 \pm 0.03$ & $0.0015 \pm 0.0002$ & $0.5 \pm 0.03$ & $0.0015 \pm 0.0002$ \\
\hline $6^{\text {th }}$ day & $0.70 \pm 0.03$ & $0.0030 \pm 0.0003$ & $0.68 \pm 0.02$ & $0.0025 \pm 0.0003$ & $0.61 \pm 0.02$ & $0.0019 \pm 0.0005$ & $0.58 \pm 0.04$ & $0.0016 \pm 0.0003$ \\
\hline $12^{\text {th }}$ day & $1.20 \pm 0.03$ & $0.004 \pm 0.002$ & $1.1 \pm 0.03$ & $0.0038 \pm 0.0004$ & $0.9 \pm 0.05$ & $0.0035 \pm 0.0006$ & $0.7 \pm 0.04$ & $0.00280 \pm 0.0004$ \\
\hline $18^{\text {th }}$ day & $1.80 \pm 0.02$ & $0.028 \pm 0.004$ & $1.6 \pm 0.03$ & $0.016 \pm 0.002$ & $1.2 \pm 0.02$ & $0.004 \pm 0.002$ & - & - \\
\hline $24^{\text {th }}$ day & $2.50 \pm 0.04$ & $0.070 \pm 0.003$ & $2.4 \pm 0.02$ & $0.068 \pm 0.002$ & $1.9 \pm 0.04$ & $0.038 \pm 0.002$ & - & - \\
\hline $30^{\text {th }}$ day & $3.10 \pm 0.06$ & $0.096 \pm 0.002$ & $3.0 \pm 0.02$ & $0.094 \pm 0.003$ & $2.3 \pm 0.05$ & $0.079 \pm 0.004$ & - & - \\
\hline $40^{\text {th }}$ day & $3.60 \pm 0.04$ & $0.142 \pm 0.005$ & $3.5 \pm 0.01$ & $0.140 \pm 0.001$ & $2.7 \pm 0.03$ & $0.086 \pm 0.002$ & - & - \\
\hline
\end{tabular}

Values are expressed as mean $\pm \mathrm{SE}$

\subsubsection{Handling stress}

The initial average length and weight were measured for samples of control groups and different treatment groups. The initial mean length and weight were $0.5 \mathrm{~cm}$ and $0.0015 \mathrm{~g}$ respectively. The group $\mathrm{HS}_{2}$ was handled only on $6^{\text {th }}$ day (when the larvae were $6 \mathrm{DPH}$ ), reduction in average length and weight of the previously stressed group $\mathrm{HS}_{1}$ was noted on $6^{\text {th }}$ day sampling. Similarly $\mathrm{HS}_{3}, \mathrm{HS}_{4}$,
$\mathrm{HS}_{5}$ and $\mathrm{HS}_{6}$ were handled on 12, 18, 24 and $30 \mathrm{DPH}$ respectively and showed reduced length and weight compared to the control groups at different sampling periods. On $40^{\text {th }}$ day, no handling was done, only sampling was done for all previously stressed groups which showed reduced growth rate in comparison to control groups (Table 2). 
Table 2. Average length and weight of catla subjected to handling stress (HS)

\begin{tabular}{|c|c|c|c|c|c|c|c|c|c|c|c|c|c|c|}
\hline \multirow[b]{2}{*}{$\begin{array}{l}\text { Sampling } \\
\text { days }\end{array}$} & \multicolumn{2}{|c|}{ Control } & \multicolumn{2}{|l|}{$\mathrm{HS}_{1}$} & \multicolumn{2}{|l|}{$\mathrm{HS}_{2}$} & \multicolumn{2}{|l|}{$\mathrm{HS}_{3}$} & \multicolumn{2}{|l|}{$\mathrm{HS}_{4}$} & \multicolumn{2}{|l|}{$\mathrm{HS}_{5}$} & \multicolumn{2}{|l|}{$\mathrm{HS}_{6}$} \\
\hline & $\mathrm{L}(\mathrm{cm})$ & W(g) & $\mathrm{L}(\mathrm{cm})$ & $\mathrm{W}(\mathrm{g})$ & $\mathrm{L}(\mathrm{cm})$ & $\mathrm{W}(\mathrm{g})$ & $\mathrm{L}(\mathrm{cm})$ & $\mathrm{W}(\mathrm{g})$ & $\mathrm{L}(\mathrm{cm})$ & $\mathrm{W}(\mathrm{g})$ & $\mathrm{L}(\mathrm{cm})$ & $\mathrm{W}(\mathrm{g})$ & $\mathrm{L}(\mathrm{cm})$ & $\mathrm{W}(\mathrm{g})$ \\
\hline $3^{\text {rd }}$ day & $\begin{array}{l}0.5 \pm \\
0.03\end{array}$ & $\begin{array}{l}0.0015 \pm \\
0.0002\end{array}$ & $\begin{array}{l}0.5 \pm \\
0.03\end{array}$ & $\begin{array}{l}0.0015 \pm \\
0.0005\end{array}$ & - & - & - & - & - & - & - & - & - & - \\
\hline $6^{\text {th }}$ day & $\begin{array}{l}0.8 \pm \\
0.03\end{array}$ & $\begin{array}{l}0.0030 \pm \\
0.001\end{array}$ & $\begin{array}{l}0.58 \pm \\
0.04\end{array}$ & $\begin{array}{l}0.0017 \pm \\
0.001\end{array}$ & $\begin{array}{l}0.7 \pm \\
0.03\end{array}$ & $\begin{array}{l}0.0028 \pm \\
0.0006\end{array}$ & - & - & - & - & - & - & - & - \\
\hline $12^{\text {th }}$ day & $\begin{array}{l}1.3 \pm \\
0.05\end{array}$ & $\begin{array}{l}0.005 \pm \\
0.001\end{array}$ & $\begin{array}{l}0.9 \pm \\
0.06\end{array}$ & $\begin{array}{l}0.0034 \pm \\
0.001\end{array}$ & $\begin{array}{l}1.1 \pm \\
0.06\end{array}$ & $\begin{array}{l}0.0038 \pm \\
0.0003\end{array}$ & $\begin{array}{l}1.2 \pm \\
0.09\end{array}$ & $\begin{array}{l}0.004 \pm \\
0.001\end{array}$ & - & - & - & - & - & - \\
\hline $18^{\text {th }}$ day & $\begin{array}{l}1.9 \pm \\
0.04\end{array}$ & $\begin{array}{l}0.036 \pm \\
0.004\end{array}$ & $\begin{array}{l}1.6 \pm \\
0.03\end{array}$ & $\begin{array}{l}0.014 \pm \\
0.004\end{array}$ & $\begin{array}{l}1.4 \pm \\
0.05\end{array}$ & $\begin{array}{l}0.009 \pm \\
0.006\end{array}$ & $\begin{array}{l}1.3 \pm \\
0.03\end{array}$ & $\begin{array}{l}0.005 \pm \\
0.002\end{array}$ & $\begin{array}{l}1.7 \pm \\
0.04\end{array}$ & $\begin{array}{l}0.02 \pm \\
0.01\end{array}$ & - & - & - & - \\
\hline $24^{\text {th }}$ day & $\begin{array}{l}2.5 \pm \\
0.04\end{array}$ & $\begin{array}{l}0.072 \pm \\
0.003\end{array}$ & $\begin{array}{l}2.0 \pm \\
0.08\end{array}$ & $\begin{array}{l}0.048 \pm \\
0.004\end{array}$ & $\begin{array}{l}1.9 \pm \\
0.04\end{array}$ & $\begin{array}{l}0.034 \pm \\
0.001\end{array}$ & $\begin{array}{l}1.6 \pm \\
0.04\end{array}$ & $\begin{array}{l}0.018 \pm \\
0.004\end{array}$ & $\begin{array}{l}1.8 \pm \\
0.05\end{array}$ & $\begin{array}{l}0.028 \pm \\
0.007\end{array}$ & $\begin{array}{l}2.4 \pm \\
0.09\end{array}$ & $\begin{array}{l}0.064 \pm \\
0.006\end{array}$ & - & - \\
\hline $30^{\text {th }}$ day & $\begin{array}{l}3.1 \pm \\
0.06\end{array}$ & $\begin{array}{l}0.098 \pm \\
0.003\end{array}$ & $\begin{array}{l}2.6 \pm \\
0.04\end{array}$ & $\begin{array}{l}0.080 \pm \\
0.005\end{array}$ & $\begin{array}{l}2.2 \pm \\
0.03\end{array}$ & $\begin{array}{l}0.06 \pm \\
0.003\end{array}$ & $\begin{array}{l}2.0 \pm \\
0.05\end{array}$ & $\begin{array}{l}0.052 \pm \\
0.006\end{array}$ & $\begin{array}{l}1.9 \pm \\
0.05\end{array}$ & $\begin{array}{l}0.036 \pm \\
0.007\end{array}$ & $\begin{array}{l}2.5 \pm \\
0.05\end{array}$ & $\begin{array}{l}0.072 \pm \\
0.006\end{array}$ & $\begin{array}{l}3.0 \pm \\
0.05\end{array}$ & $\begin{array}{l}0.092 \pm \\
0.04\end{array}$ \\
\hline $40^{\text {th }}$ day & $\begin{array}{l}3.6 \pm \\
0.04 \\
\end{array}$ & $\begin{array}{l}0.142 \pm \\
0.006 \\
\end{array}$ & $\begin{array}{l}2.9 \pm \\
0.04 \\
\end{array}$ & $\begin{array}{l}0.092 \pm \\
0.004 \\
\end{array}$ & $\begin{array}{l}2.6 \pm \\
0.02 \\
\end{array}$ & $\begin{array}{l}0.078 \pm \\
0.006 \\
\end{array}$ & $\begin{array}{l}2.2 \pm \\
0.03 \\
\end{array}$ & $\begin{array}{l}0.060 \pm \\
0.009 \\
\end{array}$ & $\begin{array}{l}2.1 \pm \\
0.02 \\
\end{array}$ & $\begin{array}{l}0.056 \pm \\
0.005 \\
\end{array}$ & $\begin{array}{l}2.7 \pm \\
0.03 \\
\end{array}$ & $\begin{array}{l}0.084 \pm \\
0.002 \\
\end{array}$ & $\begin{array}{l}3.2 \pm \\
0.06 \\
\end{array}$ & $\begin{array}{l}0.102 \pm \\
0.07 \\
\end{array}$ \\
\hline
\end{tabular}

Values are expressed as mean $\pm \mathrm{SE}$

\subsection{Cortisol response to crowding and handling in catla}

\subsubsection{Crowding stress}

The data on effect of crowding stress are presented in the Fig 1. Cortisol was detectable in the four groups, namely $\mathrm{T}_{1}: 3000 / \mathrm{m}^{2} ; \quad \mathrm{T}_{2}: 6000 / \mathrm{m}^{2} ; \quad \mathrm{T}_{3}: 12000 / \mathrm{m}^{2}$ and $\mathrm{T}_{4}: 18000 / \mathrm{m}^{2}$. Significantly, lower level $(\mathrm{P}<0.05)$ of cortisol were detected in $T_{1}$ compared to $T_{2}$ and $T_{3}$ in
3DPH. Moreover, the significant increased levels of cortisol were noted in all the higher stocking groups at the respective sampling periods. The highest cortisol levels were found in $\mathrm{T}_{3}$ at $18 \mathrm{DPH}(54.6 \mathrm{ng} / \mathrm{ml})$ and then declined sharply up to $40 \mathrm{DPH}$. In $\mathrm{T}_{4}$, cortisol levels rose very sharply up to $12 \mathrm{DPH}$, and all the fish in this group died thereafter.

\section{- T1 $=\mathrm{T} 2=\mathrm{T} 3=\mathrm{T} 4$}

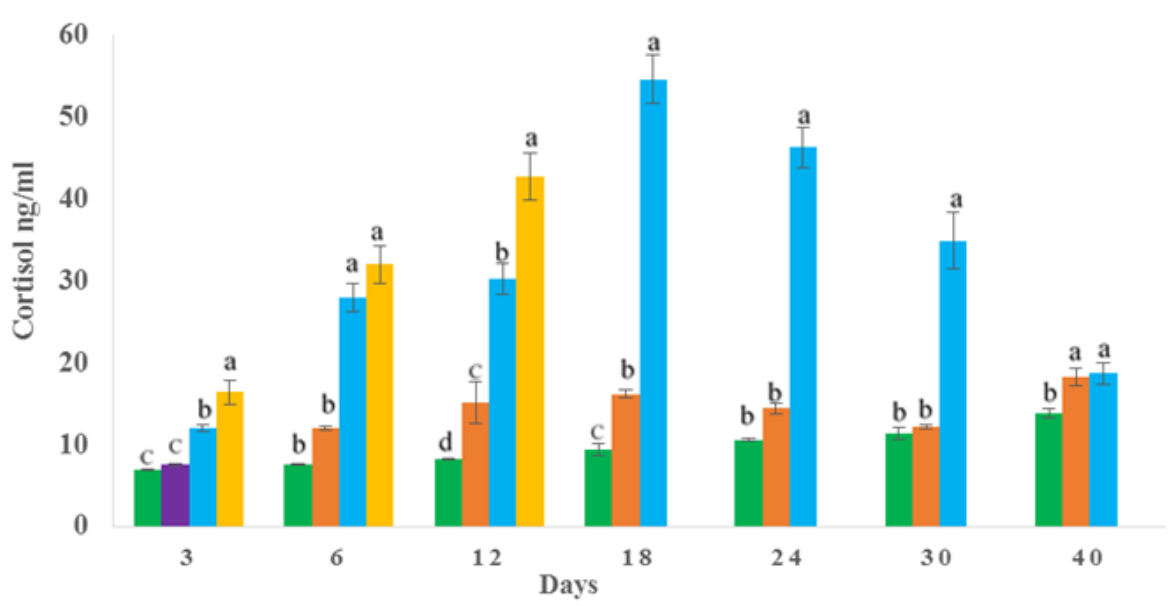

Figure 1. Cortisol levels $(\mathrm{ng} / \mathrm{ml})$ in response to crowding stress of catla. Different letters indicate significant differences $(\mathrm{P}<0.05)$ between groups (Mean $\pm \mathrm{SE}$ ).

\subsubsection{Handling stress}

The data on the cortisol response to handling stress of different age groups of spawn and fry of catla are presented in the Table 3.There was a sharp increase in cortisol levels in the early handled period $\left(\mathrm{HS}_{1}\right)$. There were significantly higher $(\mathrm{P}<0.05)$ cortisol levels in $\mathrm{HS}_{2}$ and $\mathrm{HS}_{1}$ groups compared to control. Similarly, cortisol levels were significantly elevated in different stressed groups $\left(\mathrm{HS}_{3}, \mathrm{HS}_{4}, \mathrm{HS}_{5}\right.$ and $\mathrm{HS}_{6}$ ) in comparison to the control handled in different sampling periods. The highest cortisol level were detected in $\mathrm{HS}_{6}$ stress group (100 \pm 7.10 $\mathrm{ng} / \mathrm{ml})$ at $40 \mathrm{DPH}$. The cortisol level were returned to normal levels in $\mathrm{HS}_{1}, \mathrm{HS}_{2}$ and $\mathrm{HS}_{3}$ with non-significant level with control group at $40 \mathrm{DPH}$; however, values remained significantly higher in $\mathrm{HS}_{4}, \mathrm{HS}_{5}$ and $\mathrm{HS}_{6}$ groups. The values in those groups were declining, indicating that they would return to normal level. 
Table 3. Cortisol levels (ng/ml) in response to handling stress of catla.

\begin{tabular}{|c|c|c|c|c|c|c|c|}
\hline Sampling days & Control & $\mathrm{HS}_{1}$ & $\mathrm{HS}_{2}$ & $\mathrm{HS}_{3}$ & $\mathrm{HS}_{4}$ & $\mathrm{HS}_{5}$ & $\mathrm{HS}_{6}$ \\
\hline $3^{\text {rd }}$ day & $7.1 \pm 0.84^{\mathrm{b}}$ & $46.2 \pm 2.80^{\mathrm{a}}$ & - & - & - & - & - \\
\hline $6^{\text {th }}$ day & $8.0 \pm 0.52^{c}$ & $31.3 \pm 1.70^{\mathrm{b}}$ & $54.6 \pm 2.86^{\mathrm{a}}$ & - & - & - & - \\
\hline $12^{\text {th }}$ day & $8.8 \pm 0.84^{\mathrm{d}}$ & $23.8 \pm 2.34^{c}$ & $38.2 \pm 1.15^{\mathrm{b}}$ & $64.5 \pm 3.52^{\mathrm{a}}$ & - & - & - \\
\hline $18^{\text {th }}$ day & $9.1 \pm 0.88^{\mathrm{e}}$ & $19.2 \pm 2.28^{\mathrm{d}}$ & $32.4 \pm 2.18^{\mathrm{c}}$ & $48.6 \pm 2.88^{b}$ & $86.2 \pm 4.62^{\mathrm{a}}$ & - & - \\
\hline $24^{\text {th }}$ day & $10.4 \pm 1.21^{\mathrm{fe}}$ & $15.7 \pm 1.18^{\text {ed }}$ & $25.8 \pm 1.65^{\mathrm{d}}$ & $39.6 \pm 3.32^{c}$ & $62.4 \pm 5.20^{\mathrm{b}}$ & $90.1 \pm 5.37^{\mathrm{a}}$ & - \\
\hline $30^{\text {th }}$ day & $11.5 \pm 0.95^{f}$ & $14.9 \pm 0.97^{\mathrm{f}}$ & $19.3 \pm 1.70^{\mathrm{ef}}$ & $27.4 \pm 2.37^{\mathrm{df}}$ & $44.2 \pm 3.15^{c}$ & $76.4 \pm 6.27^{\mathrm{b}}$ & $100 \pm 7.10^{\mathrm{a}}$ \\
\hline 40th day & $14.1 \pm 1.141^{\mathrm{d}}$ & $13.4 \pm 1.18^{\mathrm{d}}$ & $15.2 \pm 1.13^{\mathrm{d}}$ & $18.9 \pm 1.41^{\mathrm{d}}$ & $26.4 \pm 2.27^{\mathrm{c}}$ & $34.3 \pm 2.64^{\mathrm{b}}$ & $39.2 \pm 3.74^{\mathrm{a}}$ \\
\hline
\end{tabular}

Values are expressed as mean \pm SE in the rows with different superscripts differ significantly $(\mathrm{P}<0.05)$

\subsection{Measurement of Immunoglobulins through ELISA}

\subsubsection{Immunoglobulin levels in different crowding stress} treatments during life stages of catla

The results of ELISA showed that immunoglobulins were detectable in the spawn from 3DPH onwards. The immunoglobulin levels decreased till 18DPH in $\mathrm{T}_{2}, \mathrm{~T}_{3}$ and $\mathrm{T}_{4}$ groups, although the levels were significantly higher
$(\mathrm{P}<0.05)$ in lower stocking density group $\left(\mathrm{T}_{1}\right)$. An increment level of immunoglobulins from 18DPH to the end of the research period of 40DPH were detected. Moreover, the IgM level were remarkably down-regulated in higher stressed group fishes $\left(\mathrm{T}_{3}\right)$ in comparison to treatments of lower stocking densities $T_{2}$ and $T_{1}$ at that period. The IgM levels in different treatments during different life stages are shown in Fig. 2.

- $\mathrm{T} 1 \mathrm{~T} 2 \quad \mathrm{~T} 3 \quad \mathrm{~T} 4$

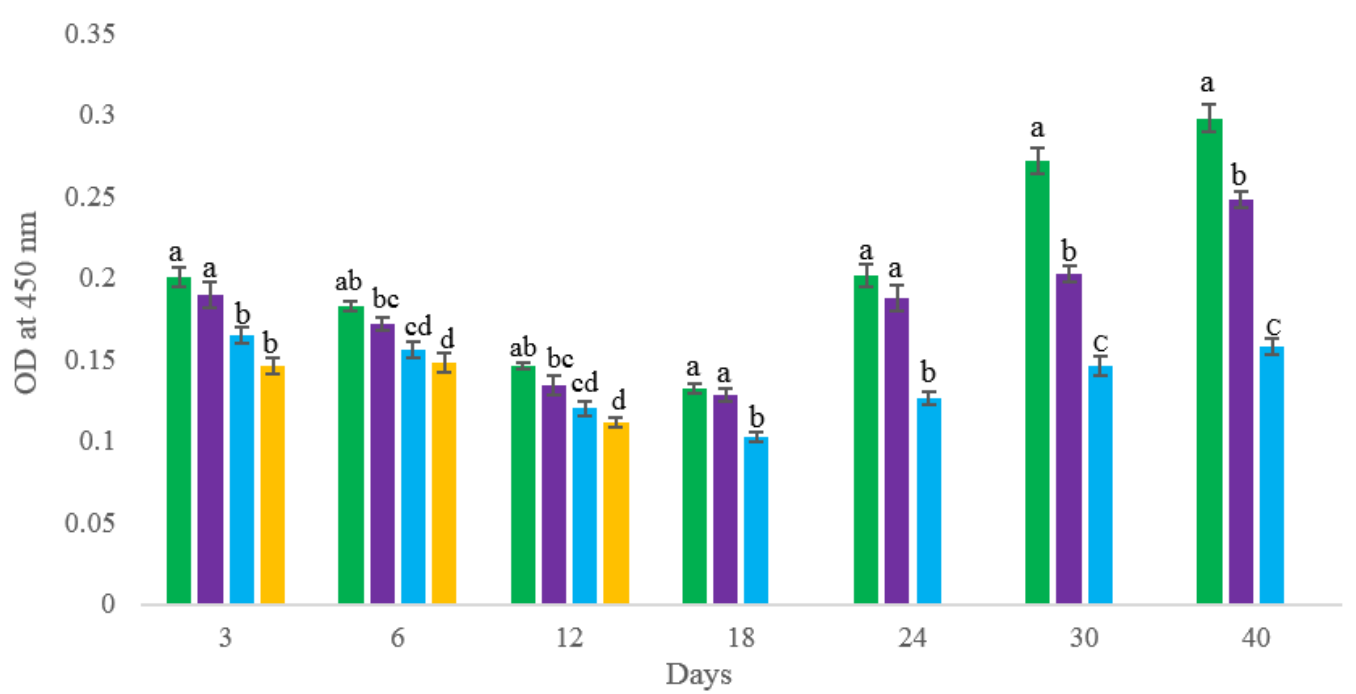

Figure 2. Immunoglobulin levels (OD) in different crowding stress of catla. Different letters indicate significant differences $(\mathrm{P}<0.05)$ between groups (Mean $\pm \mathrm{SE}$ ).

\subsubsection{Immunoglobulin levels in different handling stress treatments during life stages of catla}

The results of ELISA showed that immunoglobulins were detectable in the larvae from 3DPH. The immunoglobulin levels decreased till 18DPH. Significant elevated $(\mathrm{P}<0.05)$ levels of immunoglobulins were observed in the control group at early DPH compared to the groups of $\mathrm{HS}_{1}$ and $\mathrm{HS}_{2}$. The gradual increase was observed throughout the study period of 40th day for control groups. In response to handling, all the stressed groups have shown significant decrease $(\mathrm{P}<0.05)$ in antibody production in comparison to control $18 \mathrm{DPH}$ onwards. Other than group HS5, which was handled on 24th day, all the previously handled groups $\mathrm{HS}_{1}, \mathrm{HS}_{2}, \mathrm{HS}_{3}$ and $\mathrm{HS}_{4}$ showed significant reduction in immunoglobulin levels on 24th day. Similarly, on 30th day group $\mathrm{HS}_{6}$ was handled out of water; all the previously stressed groups including $\mathrm{HS}_{5}$ showed reduction in immunoglobulin levels. Observation on 40th day showed that there is slow recovery in all the previously stressed groups, but still the values remain significant lesser than the control. The IgM levels in different treatments during different life stages are shown in the Table 4 
Table 4. Immunoglobulin levels (OD) in different handling stress of catla.

\begin{tabular}{|c|c|c|c|c|c|c|c|}
\hline Sampling days & Control & $\mathrm{HS}_{1}$ & $\mathrm{HS}_{2}$ & $\mathrm{HS}_{3}$ & $\mathrm{HS}_{4}$ & $\mathrm{HS}_{5}$ & $\mathrm{HS}_{6}$ \\
\hline $3^{\text {rd }}$ day & $0.212 \pm 0.005^{\mathrm{a}}$ & $0.182 \pm 0.005^{b}$ & - & - & - & - & - \\
\hline $6^{\text {th }}$ day & $0.183 \pm 0.006^{\mathrm{a}}$ & $0.146 \pm 0.006^{\mathrm{b}}$ & $0.162 \pm 0.004^{\mathrm{b}}$ & - & - & - & - \\
\hline $12^{\text {th }}$ day & $0.159 \pm 0.007^{\mathrm{a}}$ & $0.131 \pm 0.006^{\mathrm{b}}$ & $0.136 \pm 0.007^{b}$ & $0.142 \pm 0.004 \mathrm{~b}^{\mathrm{a}}$ & - & - & - \\
\hline $18^{\text {th }}$ day & $0.154 \pm 0.005^{\mathrm{a}}$ & $0.123 \pm 0.005^{\mathrm{b}}$ & $0.113 \pm 0.007^{b}$ & $0.109 \pm 0.003^{\mathrm{b}}$ & $0.148 \pm 0.007^{\mathrm{a}}$ & - & - \\
\hline $24^{\text {th }}$ day & $0.225 \pm 0.004^{\mathrm{a}}$ & $0 . .141 \pm 0.005^{\mathrm{bc}}$ & $0.129 \pm 0.005^{\mathrm{dc}}$ & $0.134 \pm 0.008^{\mathrm{bc}}$ & $0.150 \pm 0.006^{\mathrm{b}}$ & $0.218 \pm 0.005^{\mathrm{a}}$ & - \\
\hline $30^{\text {th }}$ day & $0.274 \pm 0.006^{\mathrm{a}}$ & $0.153 \pm 0.008^{\mathrm{c}}$ & $0.142 \pm 0.007^{c}$ & $0.146 \pm 0.005^{c}$ & $0.154 \pm 0.003^{c}$ & $0.160 \pm 0.006^{\mathrm{c}}$ & $0.248 \pm 0.004^{\mathrm{b}}$ \\
\hline 40th day & $0.325 \pm 0.005^{\mathrm{a}}$ & $0.180 \pm 0.006^{\mathrm{c}}$ & $0.167 \pm 0.005^{\mathrm{c}}$ & $0.166 \pm 0.007^{\mathrm{c}}$ & $0.164 \pm 0.0061^{\mathrm{c}}$ & $0.174 \pm 0.004^{\mathrm{c}}$ & $0.228 \pm 0.005^{\mathrm{b}}$ \\
\hline
\end{tabular}

Values are expressed as mean $\pm \mathrm{SE}$, in the rows with different superscripts differ significantly $(\mathrm{P}<0.05)$

\section{Discussion}

Suppression of growth is often considered to be a good indicator of chronic stress. A variety of stressors challenges a fish at all times either in captivity or wild (Galhardo and Oliveira, 2009). In captivity, Nile tilapia, $O$. niloticus showed significant reduction $(\mathrm{P}<0.05)$ in the values of haemoglobin $(\mathrm{Hb})$ and other blood parameters (Ugwem et al., 2011). In captive condition of fish, overcrowding may be accompanied by additional stressors such as poor water quality, exposure to organic pollutants, and conspecific aggression and predation (Harper and Wolf, 2009).

High stocking density has been reported to cause decreased growth in salmonids (Vijayan and Leatherland, 1988) due to different factors such as decreased food consumption and social interactions (Wedemeyer, 1997) or decreased water quality (Pickering and Stewart, 1984). Moreover, high stocking density produces both hormonal and metabolic alterations (Leatherland and Cho, 1985; Schreck et al., 1985) including a reduction in thyroid hormone activity (Vijayan and Leatherland, 1988). The high stocking density has been shown to exert adverse effects on growth, and there is a negative correlation between them in the fish culture (Andrews et al., 1971; Refstie, 1982; Leatherland and Cho, 1985). The results of present study suggest that stocking density has a marked effect on growth of catla. There has been reduction in average length and weight, with increased cortisol levels in high density stressed groups in comparison to low stocking density groups, suggesting that stress induced growth suppression. Suppression of growth is often considered to be a good indicator of chronic stress (Pickering, 1990; Pankhurst and Van der Kraak, 1997; Barton and Iwama, 1991). Similarly, the present study showed reduction in average length and weight also in case of handling stress groups, with elevated levels of plasma cortisol in comparison to control. The present findings corroborated with results of Khan and Moseki (2018) reported significantly higher levels of shock proteins in both hepatopancreas and muscles of catla exposed with high light intensities. Moreover, as a consequence of stress due to intense light, a $12.5 \%$ of growth retardation was found in treated fish.

During earlier development, cortisol levels have shown a general pattern of relatively higher levels after fertilization followed by a decline until the time of hatching. It is believed that the cortisol is of maternal origin and that embryos are mobilizing the cortisol during early development (Paitz et al., 2016). Typically, the first signs of cortical tissue in teleosts are observed before hatching (Chester Jones et al., 1980), which was consistent with the findings of Stouthart et al. (1998) reported that upon handling (mechanical pressure during egg stage or netting during the larval stage) embryos and larvae increased their whole-body cortisol levels. In the present study conducted on catla spawn and fry, all the stressed groups showed sharp increase in cortisol levels in response to acute handling throughout the study period. In general, plasma cortisol levels rise at the beginning of high stocking density condition and decrease to initial values in a few days (Pickering and Stewart, 1984; Tort et al., 2004), indicated the adaptation of the fish to the new situation. This effect has been described for different species, including coho salmon (Patino et al., 1986) and Arctic charr Salvelinus alpinus (Jorgensen et al., 1993). Vijayan et al. (1990) found high plasma cortisol values in brown trout held at high stocking density. However, in the present study, fish held at high stocking density showed significantly higher levels of plasma cortisol than those held at low density, suggesting the incapacity of these fish to reach adaptation under these conditions. A similar elevation of plasma cortisol with high rearing density has been described for Atlantic salmon, Salmo salar (Mazur and Iwama, 1993).

In the present study the IgM production in catla was observed from 3DPH for control and all the stressed groups. In the previous work by Lokesh (2009) in catla, the IgM production was reported from 21DPH onwards, the reason being the variability in the environmental conditions leading to the variability in the period of development of functional immunity. Indian major carp, catla showed lower non-specific immune values indicated its weak resistance compared with rohu, Labeo rohita (Sahoo et al., 2009). One degree fall of temperature from $28{ }^{\circ} \mathrm{C}$ resulted into

$10.7 \%$ mortality of larvae of catla (Sharma et al., 2016). The autologous production of IgM in channel catfish was first reported on $21^{\text {st }}$ day (Petrie-Hanson and Ainsworth 1999). The subsequent work by Petrie-Hanson and Ainsworth (2001) reported the appearance of IgM on $7,10,14 \mathrm{DPH}$. The first appearance of IgM in carp was reported from $2^{\text {nd }}$ week post hatch (Koumans-van Diepen et al., 1994). The present study has revealed that stress induces elevated plasma cortisol levels leading to growth suppression and reduction in IgM production as consequence of crowding stress and handling stress on ontogeny of catla, although the age at which humoral response is initiated is not affected by stress. Transportation stress demonstrated reduction in the IgM concentration and fry of catla were more sensitive to stress 
than the fingerling (Ahmed and Shenoy, 2012). In a study by Saha et al. (2004) in vitro administration of cortisol was shown to reduce the number of IgM-secreting cells and IgM secretion in common carp.

In the present study, the results show that catla held at high stocking density appear to be experiencing stress, as indicated by the significant elevation in plasma cortisol. This crowding stress affected the immune activity. The fish showed no signs of disease but displayed symptoms of immunosuppression with reduced antibody or IgM production in the early stages of development. In case of crowding stress, low stoking density groups increase in the level of Immunoglobulins were detected on 24th day and gradually increased thereafter till the study period of 40th day (Fig. 2). On the other hand, in stressed groups the increase in antibody production was very slow compared to the non-stressed group. In response to handling stress, all the stressed groups have shown significant decrease in immunoglobulin production in comparison to control 18DPH onwards (Table 4). Observation on 40th day showed that there was a slow recovery in all the previously stressed groups, but still the values remain significantly lesser than the control, clearly explaining that handling stress induced suppression in the IgM production on ontogeny of catla, but not the ontogeny of humoral immune response.

\section{Conclusion}

In our investigation, both crowding and handling stress have resulted in elevated levels of plasma cortisol as a primary response in early developmental stages of catla. As a consequence of crowding and handling stress, elevated levels of plasma cortisol had a deleterious impact on growth of catla. Both crowding and handling stress induced immune suppression on ontogeny of catla linked with elevated levels of plasma cortisol. There is no effect as the onset of ontogeny of humoral immunity, but the strength of the responses decreases with increasing level of crowding as well as handling stress. Both crowding and handling stress need to be minimized for producing healthy catla fry.

\section{Funding}

This work was funded by the project \# 8086, Department of Biotechnology (DBT), Government India.

\section{Acknowledgments}

All the authors are grateful to the DBT, India for financial supports. The $2^{\text {nd }}$ and $4^{\text {th }}$ authors are thankful to the Indian Council of Agricultural Research (ICAR) for sponsoring their Ph.D. and for the award of the Netaji Subhas International Fellowship 2015-2016.

\section{Conflict of Interest}

Authors have no conflict of interest to declare.

\section{References}

Ahmed I and Shenoy KB. 2012. Effect of transportation stress on the humoral immunity of catla fry and fingerlings. J Acad Ind Res., 1: 401-403.

Andrews JW, Knight LH, Page JW, Matsuda Y and Brown EE. 1971. Interactions of stocking density and water turnover on growth and food conversion of channel catfish reared in intensively stocked tanks. Prog Fish-Cult., 33: 197-203.

Avtalion RR and Mor A. 1992. Monomeric IgM is transferred from mother to egg in tilapias. Isr J Aquacult., 44:93-98

Bag MR, Makesh M, Rajendran KV and Mukherjee SC. 2009. Characterization of IgM of Indian major carps and their crossreactivity with anti-fish IgM antibodies. Fish Shellfish Immunol., 26: $275-278$.

Barton BA and Iwama GK. 1991. Physiological changes in fish from stress in aquaculture with emphasis on the response and effects of corticosteroids. Rev Fish Dis., 1:3-26.

Breuil G, Vassiloglou B, Pepin JF and Romestand B. 1997. Ontogeny of IgM-bearing cells and changes in the immunoglobulin M-like protein level (IgM) during larval stages in sea bass (Dicentrarchus labrax). Fish Shellfish Immunol., 7: 2943.

Chester Jones I, Mosley W, Henderson IW and Garland HO. 1980. The interrenal gland in pisces. General, comparative and clinical endocrinology of the adrenal cortex, 3:396-523.

Feist G and Schreck CB. 2001. Ontogeny of the stress response in Chinook salmon, Oncorhynchus tshawytscha. Fish Physiol Biochem., 25: 31-40.

Fuda H, Hara A, Ymazak IF and Kobayashi K. 1992. A peculiar immunoglobulin $\mathrm{M}$ (IgM) identified in eggs of chum salmon (Oncorhynchus keta). Dev Comp Immunol., 16:415-423.

Furuta T, Trongv Anichnam, Zakaguchi J, Akaba Y and Ashi H. 1995. Indirect enzyme linked immunosorbant assay (ELISA) for the detection of antibody in serum of Japanese flounder. Fisheries Sci., 61: 663-667.

Galhardo L and Oliveira RF. 2009. Psychological stress and welfare in fish. Annu. Rev. Biomed. Sci., 11: 1-20.

Harper C and Wolf JC. 2009. Morphologic effects of the stress response in fish. Ilar Journal, 50: 387-396.

Hayman JR and Lobb CJ. 1993. Immunoglobulin in the eggs of the channel catfish (Ictalurus punctatus). Dev Comp Immunol., 17: $241-248$

Honnananda BR. 2008. Monoclonal antibodies for characterization and detection of immunoglobulins of Indian Major Carp, Catla catla (Hamilton). Ph.D thesis, submitted to the Karnataka Veterinary Animal and Fisheries Sciences University, Bidar, India.

Jorgensen EH, Christiansen JS and Jobling M. 1993. Effects of stocking density on food intake, growth performance and oxygen consumption in Arctic charr (Salvelinus alpinus). Aquaculture 110: $191-204$.

Khan NA and Moseki P. 2018. Investigating the role of heat shock proteins and melanophores during stress caused by high light intensity in Indian major carp, Catla catla. Int. J. Pharm. Sci., 9: 5226-5233.

Koumans-van Diepen JCE, Taverne-Thiele JJ, Van Rens BTTM and Rombout JHWM. 1994. Immunocytochemical and flow cytometric analysis of B cells and plasma cells in carp (Cyprinus carpio L.); an ontogenetic study. Fish Shellfish Immunol., 4: 1928. 
Lavanya S, Ramesh M, Kavitha C and Malarvizhi A. 2011. Hematological, biochemical and ionoregulatory responses of Indian major carp Catla catla during chronic sub-lethal exposure to inorganic arsenic. Chemosphere, 82: 977-985.

Leatherland JF and Cho CY. 1985. Effect of rearing density on thyroid and interregnal gland activity and plasma and hepatic metabolite level in rainbow trout, Salmo gairdneri. J Fish Biol., 27: 583-592.

Lokesh J. 2009. Ontogeny of humoral immunity in Indian major carps - studies using monoclonal antibody based ELISA. M.F.Sc. thesis, submitted to the Karnataka Veterinary Animal and Fisheries Sciences University, Bidar, India

Lowry OH, Rosebrough NH, Farr AL and Randall RJ. 1951. Protein measurement with folin phenol reagent. J Biol Chem., 183: $265-275$

Mazur CF and Iwama GK. 1993. Effect of handling and stocking density on haematocrit, plasma cortisol, and survival in wild and hatchery reared Chinook salmon (Oncorhynchus tshawytscha). Aquaculture, 112: 291-299.

Okpashi VE, Ogugua VN, Ubani CS and Juliet NO. 2018. An evaluation of contaminant body burdens in selected fish species: associating toxicity to upgrade the hazard assessment. Jordan $J$ Biol Sci., 11:171-177.

Paitz RT, Bukhari SA and Bell AM. 2016. Stickleback embryos use ATP-binding cassette transporters as a buffer against exposure to maternally derived cortisol. Proc R Soc Lond B Biol Sci, 283: 20152838p.

Pankhurst NW and Van Der Kraak G. 1997. Effects of stress on reproduction and growth of fish. In: Iwama, G.K., Pickering, A.D., Sumpter, J.P., Schreck, C.B. (Eds.), Fish stress and Health in Aquaculture. Cambridge University Press, UK. p. 73-93.

Patino R, Schreck CB, Banks JL and Zaugg WS. 1986. Effects of rearing conditions on the developmental physiology of smolting coho salmon. Trans Am Fish Soc., 115: 828-837.

Perumal S, Thirunavukkarasu AR and Pachiappan P. 2015. Advances in marine and brackishwater aquaculture. Springer India.

Petrie-Hanson L and Ainsworth AJ. 2001. Ontogeny of channel catfish lymphoid organs. Vet Immunol. Immunopathol., 81: 113127.

Petrie-Hanson L and Ainsworth AJ. 1999. Humoral immune responses of channel catfish (Ictalurus punctatus) fry and fingerlings exposed to Edwardsiella ictaluri. Fish Shellfish Immunol. 9:579-589.

Pickering AD. 1981. Introduction: The concept of biological stress. In Stress and Fish, Pickering, A.D., (Ed.) Academic Press, London, p. 1-10

Pickering AD, Pottinger TG and Christie P. 1982. Recovery of the brown trout, Salmo trutta L., from acute handling stress: a time course of study. J Fish Biol., 20: 229-244.

Pickering AD and Stewart A. 1984. Acclimation of the interrenal tissue of the brown trout, Salmo trutta L., to chronic crowding stress. J Fish Biol., 24: 731-740.

Pickering AD. 1990. Stress and the suppression of somatic growth in teleost fish. Prog Clin Biol Res., 342: 473-479.
Poli BM, Parisi G, Scappini F and Zampacavallo G. 2005. Fish welfare and quality as affected by pre-slaughter and slaughter management. Aquacul Int., 13: 29-49.

Refstie T. 1982. Preliminary results: difference between rainbow trout families in resistance against vibriosis and stress. Dev Comp Immunol., 2: 205-209

Saha NR, Usami T and Suzuki Y. 2004. In vitro effects of steroid hormones on IgM-secreting cells and IgM secretion in common carp (Cyprinus carpio). Fish Shellfish Immunol., 17: 149-158.

Sahoo PK, Kumari J and Mishra BK. 2005. Non-specific immune responses in juveniles of Indian major carps. J Appl Ichthyol., 21: 151-155.

Schreck CB, Patino R, Pring CK, Winton JR and Holway JE. 1985. Effects of rearing density on indices of smoltification and perfomance of coho salmon, Oncorhynchus kitsutch. Aquaculture, 45:345-358.

Sharma JG, Singh SP, Mittal P and Chakrabarti R. 2016. Impact of temperature gradient on the Indian major carp Catla catla larvae. Proc Natl Acad Sci India Sect B Biol Sci., 86: 269-273.

Stouthart AJHX, Lucassen ECHET, Van Strien FJC, Balm PHM, Lock RAC and Wendelaar Bonga SE. 1998. Stress responsiveness of the pituitary-interrenal axis during early life stages of common carp (Cyprinus carpio). J Endocrinol., 157:127-137

Sunyer JO, Gomez E, Navarro V, Quesada H and Tort L. 1995. Physiological responses and depression of humoral components of the immune system in gilthead seabream (Sparus aurata) following daily acute stress. Can J Fish Aquat Sci., 52: 23392346.

Takemura A. 1993. Changes in an immunoglobulin M (IgM)-like protein during larval stages in tilapia, Oreochromis mossambicus. Aquaculture, 115: 233-241.

Tengjaroenkul B and Neeratanaphan L. 2020. Acute effect of cadmium chloride on chromosomal abnormalities in the Nile tilapia fish In Vivo. Jordan J Biol Sci., 13:127-132

Tort L, Balasch JC and Mackenzie S. 2004. Fish health challenge after stress. Indicators of immunocompetence. Contrib Sci., 2: 443- 454.

Ugwem U, Ojo AG and Funkeye E. 2011. Haematological responses of Wild Nile Tilapia Oreochromis niloticus after acclimation to captivity. Jordan J Biol Sci., 4: 225-230.

Vijayan MM, Ballantyne JS and Leatherland JF. 1990. High stocking density alters the energy metabolism of brook charr, Salvelinus fontinalis. Aquaculture 88: 371-381.

Vijayan MM and Leatherland JF. 1988. Effect of stocking density on the growth and stress-response in brook charr, Salvelinus fontinalis. Aquaculture, 75: 159-170.

Wedemeyer GA. 1997. Effects of rearing conditions on the health and physiological quality of fish in intensive culture. In: Fish Stress and Health in Aquaculture Iwama, G.K., Pickering, A.D., Sumpter, J.P.and Schrek, C.B. (Eds), Society for Experiment Biology, Seminar Series 62. Cambridge: Cambridge University Press, p. 35-72.

Yousif AN, Albright LJ and Evelyn TPT. 1995. Immunological evidence for the presence of an IgM-like immunoglobulin in the eggs of coho salmon Oncorhynchus kisutch. Dis Aquat Org., 23:109-114. 